\title{
Macrozoobentos Diversity Index as a Bioindicator in Krueng Cunda River to Support the Success of the Shrimp Agribusniness at Lhokseumawe City, Aceh
}

\author{
Eka Maida, Adhiana and Zuriani
}

Faculty of Agriculture, Departement of Agribusiness, Universitas Malikussaleh, Muara Batu, Indonesia

\begin{abstract}
Purpose - The purpose of this research is to examine the diversity of macrozoobenthos as well as its relationship with water quality and substrate in the pond culture area.

Design/Methodology/Approach - The method of sampling area is on five observation stations by purposive sampling. The research was done indirectly (ex situ) for macrozoobenthic identification at the Ecology Laboratory, Faculty of Mathematics and Natural Sciences.

Findings - The fairness/uniformity index obtained from the five research stations ranging from 0.483 to 0.923 indicates a high degree of uniformity. This indicates that the macrozoobenthos biological index at the study site can be used as an indicator that water quality is in good condition and has the potential to be developed into an aquaculture area as well as supporting the success of the shrimp farming as one of the subsystems of the shrimp agribusiness.

Research Limitations/Implications - This research can be a source of information for the management and utilization of environment in the research area, so that shrimp harvest can be optimized in the pond farming area.

Originality/Value - This research has found that macrozoobenthos included 61 species.
\end{abstract}

Keywords Macrozoobenthos, water quality, bioindicator, shrimp farming

All papers within this proceedings volume have been peer reviewed by the scientific committee of the Malikussaleh International Conference on Multidisciplinary Studies (MICoMS 2017).

\section{Introduction}

Macrozoobenthos in water can be used as an indicator of the quality of the aquatic environment as they may reflect changes in environmental factors including the level of environmental pollution over time (Oey, 1978 in Maulana, 2010). Macrozoobentos can be used as biological parameters in determining the condition of ponds or rivers because their life is relatively silent based on ponds or rivers. The purpose of this research is to see the

(C) Eka Maida, Adhiana, Zuriani. Published in the Emerald Reach Proceedings Series. Published by Emerald Publishing Limited. This article is published under the Creative Commons Attribution (CC BY 4.0) licence. Anyone may reproduce, distribute, translate and create derivative works of this article (for both commercial and non-commercial purposes), subject to full attribution to the original publication and authors. The full terms of this licence may be seen at http://creativecommons.org/ licences/by/4.0/legalcode 
diversity of macrozoobenthos and its relationship with water quality and subtract on river area which becomes water source for pond culture. This research area is a river flow mixed with sea water (estuaria) and has a feature that this area is a sea area which divides the mainland of Sumatera island to the strait. The flow of water that irrigates the pond area comes from salt water because its position is in the strait area. This area has important roles for the society, such as cultivating groupers, snapper, shrimp, crab, and also oysters.

The management of coastal environments as cultivated land to boost shrimp production sustainability should be done taking into the natural capabilities established by biodiversity. Improvement in environmental quality will artificially cost and high risk, so the concept of natural recovery is the best alternative. Biotic and abiotic components in coastal areas have specific roles, but they are interconnected with each other to maintain the stability and fertility of cultivated land in coastal areas. Macrozoobenthos have sensitivity to some contaminants, low mobility, easily to catch, and long-lived. Therefore, the role of macrozoobenthos is to maintain the balance of aquatic ecosystems including cultivated land can be an indicator of recent ecological conditions in a particular area. The main problem is how to improve the amount of shrimp harvest. This study aims to see the diversity of macrozoobenthos as well as its relationship with water quality and subtract in pond culture area. The results of this study are expected to be an information for the management and utilization of the environment in the coastal areas of research for the utility of pond farming and optimizing the results of shrimp harvest.

\section{Methodology}

\subsection{Time and location}

The research was conducted in May 2017 until June 2017 along the Krueng Cunda River which is the source of water for the Lhokseumawe's aquaculture area. Sampling area is on five observation stations by purposive sampling. The research was done indirectly (ex situ) for macrozoobenthic identification at Ecology Laboratory Faculty of Mathematics and Natural Sciences.

\subsection{Tools and materials research}

The tools and materials used in this research are the tools for measuring the physical condition and chemistry of the water environment, Global Position System was used to determine the coordinates of the research station, and Identification Book Tropical Pacific Invertebrate used to identify the macrozoobenthos species and sampling tools macrozoobenthos. The other materials are plastics, plastic bags, sample bottles, stopwatch, label paper, markers, and digital camera.

\subsection{Sampling method}

Determination of observation station is using purposive sampling method at five observation stations based on consideration of ecological condition. Sampling was done by method of transect line plots systematically randomized. Each observation station is divided into three substations in the form of a 100 -m transect line which is operated perpendicular to the coastline. For taking macrozoobenthos, each substation is divided into three plots $(10 \times 10) \mathrm{m}^{2}$. Samples of macrozoobenthos were taken with the surber net by means of dredging the substrate three times. The obtained macrozoobenthos samples were sorted and then inserted in $40 \%$ formalin filled sample vessels then identified in the laboratory. Water samples were taken at each station without in situ repeats and substrate sampling was performed using a 4 inch diameter paralonic pipe to a depth of $10 \mathrm{~cm}$, then the substrate was stored in plastic and labeled for further analysis in the laboratory. 


$$
H^{\prime}=-\sum p i \ln p i \text { where } p i=\frac{n i}{N}
$$

Macrozoobenthos Diversity Index as Bioindicator

$H^{\prime}=$ diversity index

$n i=$ the number of individual taxa $i$

$N=$ total number of individuals

$P i=$ proportion of species $i$

Uniformity/Evenness Index Type/Evenness Index (E) (Fachrul, 2007):

$$
E=\sum \frac{H^{\prime}}{H m a k s}
$$

with:

$$
E=\text { uniformity index }
$$

$H^{\prime}=$ diversity index

Hmaks = maximum diversity index

Index dominance (Odum, 1994):

$$
D=\sum p i^{2}
$$

with:

$D=$ index of dominance

$N i=$ the number of individual taxa $i$

$N=$ total number of individuals

$P i=n i / N=$ proportion of species $i$

\section{Results and discussion}

\subsection{Geographical condition of research sites}

The research location is located at Kota Lhokseumawe in $04^{\circ} 54^{\prime}$ to $05^{\circ} 18^{\prime}$ North Latitude and $96^{\circ} 20^{\prime}$ to $97^{\circ} 21^{\prime}$ East Longitude, staple by the Malacca Strait. The research location is the area of the river that irrigates aquaculture. Map of research area illustrated in Figure 1.

\subsection{Density and composition type of macrozoobenthos}

The results of the analysis consist of macrozoobenthos community structure (number of individuals and macrozoobenthos type composition, diversity index, uniformity index, and dominance).

(1) Density of macrozoobenthos:

The total number of individual macrozoobenthos obtained during the sequential study of the highest was 293 individuals $/ \mathrm{m}^{3}$ at station I, 194 individuals $/ \mathrm{m}^{3}$ at station II, 109 individuals $/ \mathrm{m}^{3}$ at station III, 51 individuals $/ \mathrm{m}^{3}$ at station IV, and 31 individuals $/ \mathrm{m}^{3}$ at station 5 . 
Proceedings of

MICoMS 2017

160

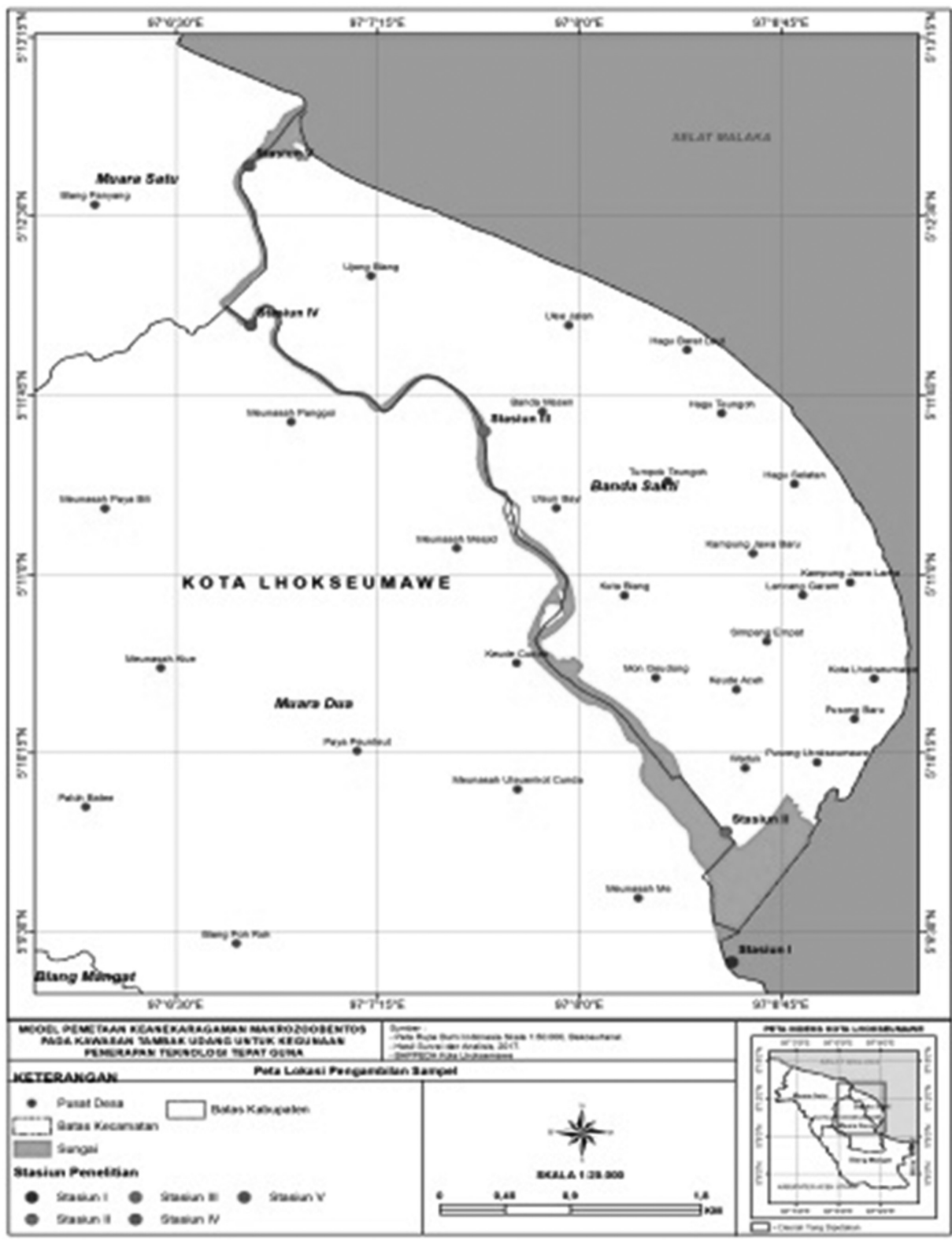

(2) The composition of macrozoobenthos:

The macrozoobenthos composition at the study sites consisted of $19 \%$ Annelida, $37 \%$ Bivalves, $2 \%$ Crustaceans, $40 \%$ Gastropods, 0.4\% Holothuroidea, $0.1 \%$ Insecta, $1.3 \%$ Malacostraca, and $0.1 \%$ Oligochaeta. The five sampling stations 
that have been conducted are dominated by species from the Gastropoda class and bivalves.

(3) Diversity index, uniformity index, and dominance index:

Overall the results of the analysis can be seen in comprising the index of macrozoobenthos diversity in the five research stations ranging from 1.056 to 2.500. The fairness/uniformity index obtained from the five research stations ranged from 0.483 to 0.923 . The dominant index of the five research stations ranged from 0.099 to 0.520 .

The research location is located at Krueng Cunda River is the source of water for the cultivation of Lhokseumawe municipal pond. It is the expanse of fishery aquaculture pond development which is dominated by the maintenance of shrimp commodity, milkfish, and also keramba floating. Cultivation production obtained by farmers community still fluctuate because the cultivation method applied is still different, that is, traditional and semiintensive and intensive

The results showed that the number of individual macrozoobenthos found in observation stations in the Krueng cunda River were 61 species consisting of eight classes, Annelida, Bivalvia, Crustacea, Gastropoda, Holothuroidea, Insecta, Malacostraca, and Oligochaeta. Bivalves and Gastropada are the ever-present classes at every station. The number of classes of Gastropoda and Bivalvia allegedly related to the substrate contained in each station, namely in the form of mud, sandy mud, dusty soil to clay. The type of Gastropoda and Bivalvia can grow and develop on muddy substrate types because it has a special physiology of long siphon (Nybakken, 1988) . Cerithidea cingulata dominates the species against other species in all research stations. According to Marpaung (2013), Cerithidea cingulata is one of the benthos whose habitat is on a muddy substrate like a substrate in a pond. The presence of dominance due to the highly favorable environmental conditions in favor of the growth of certain species.

The macrozoobenthos composition at the study site consisted of 19\% Annelida, 37\% Bivalves, 2\% Crustaceans, $40 \%$ Gastropods, $0.4 \%$ Holothuroidea, $0.1 \%$ Insecta, $1.3 \%$ Malacostraca, $0.1 \%$ Oligochaeta (Figure 2). The five sampling stations that have been conducted are dominated by species from the Gastropoda and Bivalvia class. The number of classes of Gastropoda and Bivalvia allegedly related to the substrate contained in each station, namely in the form of mud, sandy mud, dusty soil to clay. According to Nybakken (1988), the type of Gastropoda and Bivalvia can grow and develop on muddy substrate types because it has a special physiology of long siphon.

Cerithidea cingulata is a species found in the five research station sites, it is suspected that the adaptation of this species is high. According to Syamsurisal (2011), this type of Cerithidea cingulata has a thick and strong shell, columella usually rolled up and has a short canal. Body structure like this causes the organism is not easily preyed by predators, so its existence is always abundant.

Differences in macrozoobenthos composition in each station show that macrozoobenthos communities have specific adaptations to the environmental and ecological conditions to be viable, to grow, and to breed (Pong and Andi, 2006). The macrozoobenthos diversity index in the five research stations is moderate from 1.056 to 2.500. Moderate (moderate) community conditions are a volatile community condition only with relatively small environmental influences. The value of $H^{\prime}<1$ then the biota community is categorized as unstable, and if the value of $H^{\prime}$ ranges from 1 to 3 , then the stability of the biota community is moderate, and if the value of $H^{\prime}>3$ then the community of biota is categorized in good condition (Pong and Andi, 2006). 
Proceedings of MICoMS 2017

\section{2}

Figure 2.

Composition of Macrozoobentos throughout the Station

\section{All}

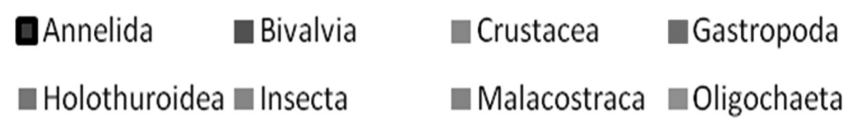

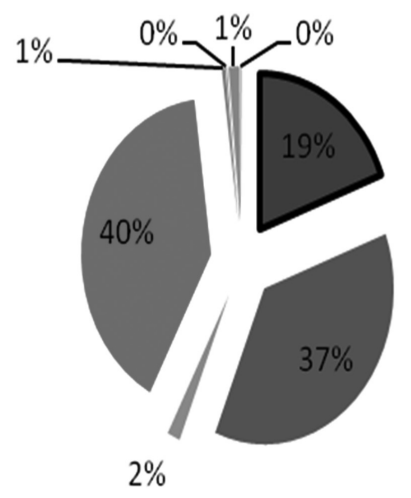

The diversity index at station 5 is higher than the other four stations, presumably because this station is located in the estuary area close to the fishing dock. The value of low diversity index is found in stations $1,2,3$, and 4 , it is suspected that this station is close to the residential area of residents. The existence of environmental zone differences causes the diversity of the intolerant organisms to decline, otherwise the tolerant organisms will be high. Suwondo et al. (2004) mentions that there is a close relationship between diversity and environmental quality.

The fairness/uniformity index obtained from the five research stations ranging from 0.483 to 0.923 indicates a high degree of uniformity. The highest uniformity indexes at stations 4 and 5 are 0.838 and 0.923 , and low at stations 1,2 , and 3 are $0.594,0.543$, and 0.483 , respectively. The number of species obtained is small and no dominant species, whereas the 4 and 5 indexes indicate high value. This is thought to be due to environmental factors that are less supportive for the life of macrozoobenthos. The value of $E$ close to 0 means uniformity of organism types in an unbalanced waters due to competition both place and food (Rosyadi and Thamrin, 2009). If the value of $\mathrm{E}$ approaches 1 indicates the uniformity of the type of organism in the waters in a state of balance because there is no competition either to place or food.

The dominant index shows the values obtained from the five research stations ranging from 0.099 to 0.520 , indicating moderate dominance. If $0<\mathrm{D}<0.5$, then the dominance is low; if $0.5<\mathrm{D}<0.75$, then the dominance is moderate; and if $0.75<\mathrm{D}<1.00$, then the dominance is high (Susiana, 2011). The highest dominant index in the embankment is at station 3 and the lowest dominant index is at station 5 . This is expected to affect the substrate type. Substrate type is the main factor that controls the distribution of macrozoobenthos. This is due to the smaller number of species and the presence of some larger individuals dominating the area (Setiawan, 2010).

\section{References}

Fachrul, F.M. (2007). Methodology of Bio-Ecological Sampling, Bumi Aksara, Jakarta.

Krebs, C. (1989) Experimental Analysis of Distribution and Abudance (3rd ed.), Harper and Row Publisher, New York, NY. 
Marpaung, A.A.F. (2013). Makrozoobenthos Diversity in Mangrove Ecosystem Silvofishery and Mangrove Natural Ecotourism Area Boe Beach Galesong District Takalar District. [Skripsi], Universitas Hasanuddin Makassar, Makassar.

Nybakken, J.W. (1988) “Marine Biology”. In M. Eidman (Ed.), An Ecological Approach Translated from Marine Biology an Ecological Approach, PT Gramedia Pustaka Utama, Jakarta pp. 1-18. [in Taqwa, A. (2010). Analysis of Primary Productivity of Phytoplankton and Community Structure of Macrobenthos Fauna Based on Mangrove Density in Mangrove Conservation Area and Bekantan Kota Tarakan Thesis, University of Diponegoro, Semarang, pp. 11-34.

Odum, E.P. (1994). Ecology Basics (3rd ed.) (Trans Samingan, T.), UGM Press, Yogyakarta.

Oey, 1978 in Maulana. (2010). "Utilization of Macrozoobentos as a Coastal Water Quality Indicator”. In P. Michael (Eds), Ecological Methods for Field and Laboratory Investigations. Reflected by Yanti R. Koestoer and Sahati Suharto. 1995, UI-Press, Jakarta.

Pong - masak P.R. and Andi, M.P. (2006) "Macrozoobentos Community at Pondok Perkak Area in Pesisir Malakosa Parigi - Moutong, Central Sulawesi”. J. Biodiversity, Vol. 7, No. 4, pp. 354-360.

Rosyadi, N.S. and Thamrin. (2009). "Distribution and Abundance of Macrozoobentos in Singingi River Riau”. Journal of Environment, Vol. 31, pp. 58-73.

Setiawan, D. (2010). Macrozoobentos Community Structure As Bioindicator of Environmental Quality of Downstream Waters in Musi River Thesis, Institut Pertanian, Bogor.

Susiana. (2011). Diversity and Density of Manggrove, Gastropoda and Bivalves at Perancak Bali Thesis, Universitas Hasanuddin, Makassar.

Suwondo, Elya, F., Dessy, and Mahmud, A. (2004). "Biological Quality of River Waters Senapelan, Sago and Sail in Pekanbaru City Based on Plankton and Bentos Bioindicators Biogenesis". Report on the zoology laboratory of PMIPA FKIP university of Riau. Pakanbaru.

Syamsurisal. (2011). Studi Beberapa Indeks Komunitas Makrozoobentos Di Hutan Manggrove Kelurahan Coppo Kabupaten Baru. Skripsi, Jurusan Perikanan Fakultas Ilmu Kelautan dan Perikanan Universitas Hasanuddin, Makasar.

\section{Corresponding author}

Ekamaida can be contacted at ekamaida@unimal.ac.id 